\title{
Don't Let Good Grammar Spoil Good Writing
}

COMMUNICATION CORNER No. 32

\author{
by Philip Yaffe
}

\section{Editor's Introduction}

Each "Communication Corner" essay is self-contained; however, they build on each other. For best results, before reading this essay and doing the exercise, go to the first essay "How an Ugly Duckling Became a Swan," then read each succeeding essay.

It seems that if your grammar is good, your writing will be good. However, being overly concerned about good grammar can actually be detrimental to good writing. Here's why. 


\title{
Don't Let Good Grammar Spoil Good Writing
}

\author{
COMMUNICATION CORNER No. 32
}

\section{by Philip Yaffe}

If saying that good grammar can spoil good writing sounds like heresy, it was meant to.

When I search the web for writing tips, all too often the first bit of advice that comes back is "Be sure to use good grammar." But that's putting the cart before the horse. It's like telling a carpenter which hammer to use to drive in a particular type of nail. Very useful advice; however, it's a detail. It is valid only if the carpenter already knows why he is putting the nail there and what will follow.

There is a second reason why this bit of advice is misplaced. One person's idea of good grammar is not necessarily another's.

The English language is not blessed (or cursed) with the equivalent of the Académie Française, a more or less official body in France that regulates the French language. Differences about correct grammar are sometimes hotly argued within the Académie, but outside their decisions are accepted as law.

English grammarians also are continually arguing with each other. There is of course broad agreement on many things. However, when there isn't, you can pretty much do as you please.

Over my nearly 50-year career as a writer, I have purposely chosen to "violate" some aspects of English grammar that many people consider to be inviolable. Why? Because I believe their rigorous application often impedes emphasis and/or understanding.

I would like to share some of these with you. You may never have thought about them before, so here is your opportunity. Once you have reflected on these matters, you may accept or reject them as the mood takes you.

Although a native of Southern California, I have been living in Brussels, Belgium, for the past 46 years. In Europe, British English is generally preferred to American English, so I am quite accustomed to seeing the language used somewhat differently from what I knew before I came here. 


\section{Past versus Present Tense}

One of my particular pet peeves is something I hear daily on the BBC, the prestigious British Broadcasting Corporation. This is not a condemnation of British versus American English. It's just that I became aware of the practice while listening to the BBC. Americans do pretty much the same thing.

What am I talking about? The annoying, even ludicrous stricture that if a sentence starts in the past tense, it must remain in the past tense. For example: The United Nations this morning reported that malaria "was" still a worldwide health menace. To me, it makes much more sense to say: The United Nations this morning reported that malaria "is" still a worldwide health menace.

Or what about this: The president asserted that the economy "was" going to remain strong at least until at least 2022. Again, it makes no sense to say: The president asserted that the economy "is" going to remain strong at least until 2021.

This practice is relatively harmless; nevertheless, I cringe at it.

Clearly the speaker didn't mean to suggest the situation was likely to change almost the instant they had uttered his statement. They were projecting into the future. So while they may have said it five minutes ago (past tense), it seems ludicrous to paraphrase their statement in the past tense, which only diminishes its force.

If you believe casting the beginning of a sentence in the past tense, then the rest in the present or future tense is bad grammar, you are in poor company. When the logic of the situation calls for it, many good writers and speakers ignore the "rule." The above examples were in fact taken from two of the world's leading international daily newspapers.

\section{Capitalizing Bullet Points}

The purpose of bullet points is to make thoughts and information stand out. So why go against the current by not capitalizing the first letter of each point? For example:

\section{Example A}

Our system helps people:

- write better;

- write faster;

- write persuasively;

- reduce errors;

- reduce formatting problems. 


\section{Example B}

Our system helps people:

- Write better

- Write faster

- Write persuasively

- Reduce errors

- Reduce formatting problems

You will notice that in addition to capitalizing each bullet point, example B also eliminates the semi-colons and the period. What logic is there for putting in commas and periods? The fact that the next line is a new bullet point, i.e. clearly a new thought, makes such punctuation unnecessary, and even distracting.

Of course, it can be contended that each bullet point is a continuation of the main sentence, so starting with a capital would be incorrect. Likewise, each bullet point is the end of a thought, so punctuation is necessary.

Valid arguments, for a grammarian. However, for a writer, whatever weakens the power of bullet points negates the reason for using them in the first place. Not capitalizing and inserting punctuation both tend to weaken bullets points, and therefore should be avoided

\section{Names and Titles}

My final grammatical pet peeve may not be grammatical at all. It has to do with how people are introduced in a document. I am not certain there is any "rule" governing this; it is more a matter of choice.

\section{Example A}

The president of the International Federation of Tuba Players, John Jones, has just celebrated his 18th year of service.

\section{Example B}

John Jones, president of the International Federation of Tuba Players, has just celebrated his 18 th year of service.

Both A and B are legitimate ways of introducing John Jones. Some good writers choose the one, some choose the other. I would like to argue that in most cases, B is probably preferable because it is more "natural." After all, at a party you wouldn't say to someone, "I would like to 
introduce you to the president of the International Federation of Tuba Players, John Jones." Preferably you would say, "I would like to introduce you to John Jones, president of the International Federation of Tuba Players."

\section{Paragraphing}

This Communication Corner essay is full of a heresy that many grammarians would be happy to chastise me for-and have.

You may have noticed many of the paragraphs in the essay are quite short, even only one sentence. I am certain that you didn't learn paragraphing like this in school, and would have been marked down if you had tried it.

Some people who use "ungrammatically" short paragraphs claim they help maintain reader interest because readers dislike large blocks of text. This is true. However, there is an even better reason for using them. Short paragraphs can help to dramatize certain key idea, thereby enhancing clarity.

The first paragraph of this section is a case in point. The sentence starting "This essay is full of a heresy that ..." could easily have been combined with the next sentence starting "You may have noticed that many of the paragraphs are quite short . . ." to form a single paragraph. This is probably what most grammarians would do, and insist that others do the same. However, some of the emphasis of that first sentence would have been lost, to the detriment of clarity.

If you have doubts about using such unorthodox paragraphing, look at any leading newspaper or magazine for reassurance. Short, dramatic paragraphing is one of the things that make these popular publications so easy and enjoyable to read.

\section{About the Author}

Philip Yaffe was born in Boston, Massachusetts, in 1942 and grew up in Los Angeles, where he graduated from the University of California with a degree in mathematics and physics. In his senior year, he was also editor-in-chief of the Daily Bruin, UCLA's daily student newspaper. He has more than 40 years of experience in journalism and international marketing communication. At various points in his career, he has been a teacher of journalism, a reporter/feature writer with The Wall Street Journal, an account executive with a major international press relations agency, European marketing communication director with two major international companies, and a founding partner of a specialized marketing communication agency in Brussels, Belgium, where he has lived since 1974. He is the author of more than 30 books, which can be found easily in Amazon Kindle.

DOI: $10.1145 / 3441229$ 